\title{
Vision and Leadership: Problem-based Learning as a Teaching Tool
}

\author{
Douglas Archbald, Ph.D. \\ Associate Professor \\ 103 Willard Hall \\ Newark, DE 19716 \\ archbald@udel.edu \\ 302-831-6208
}

\begin{abstract}
We read and hear frequently about the role of vision in leadership. Standards for leadership education programs typically emphasize vision as a core component of leadership education and published accounts of successful leadership usually extol the leader's vision. Given the prevalence of this term in discourse on leadership, it is surprising how little literature exists with specific discussions of how to teach it. In this article I discuss the potential of problem-based pedagogy for teaching the concept of vision. This paper draws on literature, theory, and my professional experience as a faculty member for 20 years in a graduate-level education leadership program.
\end{abstract}

\section{Background and Related Literature}

"Good business leaders create a vision, articulate the vision, passionately own the vision and relentlessly drive it to completion." (Jack Welch, ex-CEO, General Electric)

What is vision? Here are some quotations from leadership authorities:

- Vision is "a realistic, credible, attractive future... an articulation toward which you should aim, that in important ways is better, more successful, or more desirable than the present" (Nanus, 1992, p. 8).

- "Vision refers to a picture of the future with some implicit or explicit commentary on why people should strive to create that future" (Kotter, 1996, p. 68).

- "A core characteristic of all effective leaders is the ability to have a vision of where they are trying to go and to articulate it clearly to potential followers so that they know their personal role in achieving that vision" (Wilhelm, 1996, p. 223).

- "Vision is an inherently communicative act....Vision is based in the current reality [and is] concerned with a future substantially different from the present" (Douglas, Burtis, \& Pond-Burtis, 2001, p. 58).

Vision-based leadership is distinct from management (Boomer, 2012; McGowan, \& Miller, 2001). Most of the time what organizations need is sound management: managing personnel, budgets, supplies, and operations; being efficient with time, records, and reporting; evaluating 
personnel; and, addressing small problems effectively. No organization can succeed with incompetent management.

However, when complex challenges confront an organization, change is needed and vision becomes important. If an organization's leadership knows only how to manage, but not how to adapt and transform, organizational performance can suffer in times of challenge. With poor leadership and no vision of improvement, change may yield no gain and may even make things worse. While organizations in these circumstances generally survive, they may devolve to a state of chronic under-performance - operating below their potential.

Many tales of visionary leadership are in both popular and scholarly literature (Bennis, 1992; Bollier, 1996; Kotter, 1996; Slater, 1999). Much of this is business management theory or written accounts of people who created or turned around businesses - people like Mary Kay, founder and builder of a cosmetics empire and Alfred Fuller who created the Fuller Brush Company (Trice \& Beyer, 1991) or Jan Carlzon who turned failing Scandinavian Airlines into an industry leader (Bennis, 1992) or Howard Schultz who created Starbucks (Koehn, 2002). Bollier's (1996) Aiming Higher provides accounts of 25 leaders and businesses notable not just for business success but also for exercising a social vision.

These books and articles reflect one version of visionary leadership - an extraordinary individual creating a successful business or revitalizing an organization teetering on the brink of collapse. Published accounts like these put a popular form of visionary leadership in the spotlight: herolike protagonists overcoming challenges, breaking paradigms, creating new enterprises, and leaving lasting legacies. But vision is no less important for ordinary leaders in community organizations, schools, agencies, nonprofits, organizational departments and other roles like these. If a leader cannot identify problems and cannot conceive and communicate a vision of improvement, then that organization is without a critical lever for improvement (Baker, 2010; Dixon, 1999; Manning, 2012; Nanus, 1992; O'Connell, Hickerson, \& Pillutla, 2011; Pasi, 2003; Taylor, 2007; Yukl, 2001).

Research on change leadership in schools is illustrative. Most schools are managed reasonably well, but most administrators' time is not vision-based instructional leadership; rather, it is maintenance oriented: operations, logistics, schedules, and student discipline (Camburn et al., 2010; Donaldson, 2007; Horng, Klasik, \& Loeb, 2010; Leithwood, Louis, Anderson, \& Wahlstrom, 2004). Maintenance is obviously important, but it is not the same as leading with vision. While many schools are well managed, not many have leaders who can mobilize people and resources to achieve a clearly understood vision of instructional improvement. Finnigan and Stewart (2009), studying 10 urban elementary schools, found only two of the 10 principals could be categorized as transformational - that is, they articulated a clear vision of improvement, were good communicators, and effectively cultivated staff buy-in to work toward change. A similar conclusion is offered from a study of school leaders in five districts:

The "transformers" had an explicit vision of what they wanted their school to be like, and they talked about specific changes they were making now or planned to make in the near future. This year, introduce the new reading curriculum. Next year, get a teaching coach 
for math. Some had scanned their teacher rosters and pinpointed the teachers they wanted to move out. Maybe it couldn't be done in one fell swoop, but they had their plans. (Johnson, 2008, p. 26)

The copers, on the other hand, allocated almost all of their time to keeping the school running and generally felt they had nothing to give beyond this. This was their full-time job; their total commitment. It is not that these principals were not working hard; rather, they were preoccupied with day-to-day management and uninvolved in instruction. These principals did not see how they could do things differently, as illustrated in one's comment: "I find myself wearing so many hats... it's unbelievable. I just cannot free myself up."

A study focused on leadership in 15 exemplary schools showed mechanisms through which vision guided key aspects of decision making (Portin et al., 2009). For instance, personnel decisions "in one middle school, at least six teachers over a two year period had specifically chosen the school after having substituted in other schools, both within and outside the district, based on the way they were treated at the school and their perception that the school leader had a clear and compelling vision for education" (p. 53). Resource allocation decisions were driven by needs demonstrably linked with instructional improvement.

The need for leaders capable of vision is not just in education. Literature from other fields of leadership practice also shows this, indicating an undersupply of leaders understanding vision and capable of exercising it when needed (Gooch, 2012; Leslie, 2009; Weiss \& Molinaro, 2010; Zaleznik, 1990). As Kouzes and Posner (2009) noted, "The data tell us that what leaders struggle with most is communicating an image of the future that draws others in - that speaks to what others see and feel" (p. 21).

\section{On Teaching Vision}

I teach in a professional education graduate program serving practitioners from K-12 and higher education. In the next two sections, I describe a problem statement paper as a tool to teach vision, but first let me clarify my underlying assumption that vision is teachable.

To claim vision is teachable does not imply that vision is an all or none leadership attribute either you have it or you do not. We know that many attributes, dispositions, and skills necessary to exercise visionary leadership can be learned and are teachable (Barrett, Vessey, \& Mumford, 2011; Brenninkmeyer \& Spillane, 2004; Conger, 1991; Copland, 2003a; Ekmecki, 2009; Frese, Beimel, \& Schoenborn, 2003; Hackman, Kirlin, \& Tharp, 2004; Ibarra \& Obodaru, 2009; Strange \& Mumford, 2005) and that teaching and coursework are most effective when they situate leadership learning in authentic problems of practice (Archbald, 2008; Archbald, 2013; Brenninkmeyer \& Spillane, 2004; Copland, 2003a; Copland, 2003b; Duch, Gron, \& Allen, 2001; Fenwick, 2002; Grogan \& Andrews, 2002; Jean-Marie \& Normore, 2010; Savin-Baden, 2000). This does not mean that instruction can turn all students into visionary leaders or that there are no inborn leadership traits; but, this much is clear that well-designed instruction and hard work by students can help them understand vision and its role in leadership. 
I observe growth in students. Every year they improve in substantive knowledge in their field and in their skills and confidence in leadership. This growth is also revealed in our program's portfolio assessments and documentation for the National Council for Accreditation of Teacher Education (NCATE ). While it will always be the case that leaders vary in their capacity to exercise vision, this does not change the fact that everyone can learn and improve and strengthen their capability to exercise vision in appropriate leadership contexts.

\section{The Problem Statement Paper}

In a leadership communications course I assign a problem statement paper. In writing this paper, the student learns how to conceptualize a problem as a gap between current and more desirable organizational conditions or practices and how to communicate this in an evidence-based narrative argument. I call this gap analysis (Archbald, 2013) - an analytical method to conceptualize and communicate a problem.

Sessions early in the course address the question: what is a problem? Most tasks of management and leadership deal with routine matters. Most of the time the status quo and performance are acceptable and standard operating procedures are sufficient to manage small challenges. Occasionally, however, organizations face larger, more complicated and challenging problems that can undercut the organization's productivity or performance. These are problems that do not have a ready solution because they are too complex and have multiple and uncertain causes (Cuban, 2001; Jonassen \& Hung, 2008; Marcy \& Mumford, 2010; Middleton, 2002; Rittel \& Webber, 1973; Savery, 2006; Simon, 1973; Snowden \& Boone, 2007). Schon (1983), for instance, writes:

In real-world practice, problems do not present themselves to the practitioner as givens. They must be constructed from the materials of problematic situations which are puzzling, troubling, and uncertain. In order to convert a problematic situation to a problem, a practitioner must ...make sense of an uncertain situation that initially makes no sense. (p. 40)

A common label in the literature for these types of non-routine, complex, performancethreatening problems is ill-structured problems. Examples from education include problems like out-of-control bullying within a school or district, high levels of staff turnover or low morale, and staff resistance to adopting new and more effective practices such as integrating new technologies into their work routines. Challenges like these happen periodically in every organization whether in healthcare, business, government, or other sectors.

One study of problem-solving among school building administrators found that $17 \%$ of problems encountered, out of more than 900 analyzed, could be classified as non-routine (ill-structured). This study was based on about 300 hours of interviews with 52 school principals over the course of a school year. It produced a sample of 907 problems in sixteen categories; about $17 \%$ were determined to be non-routine (ill-structured) problems (Leithwood \& Steinbach, 1995). 
When complex problems are encountered, a key role of leadership is to define the problem (sometimes called "framing") - which is to say the leader plays a lead role in developing a perspective on the specific nature of the problem, its causes, and consequences. This is not a single step - the problem definition does not spring forth whole cloth after a few minutes of reflection - rather it is a process entailing inquiry, data gathering, and proposing and negotiating viewpoints; it requires a great deal of communication. How the problem is framed shapes organizational responses.

A good leader plays a pivotal, but not a solitary, role in developing a problem definition. Developing a shared problem definition is a process of co-constructing meaning involving staff and stakeholders and requires consensus building. Collective understanding and buy-in cannot be imposed unilaterally from the top. When problems arise, leadership's role is to communicate with clarity, inspiration, and credibility and to convey a vision of a better way.

Next, I discuss the assignment of defining a problem and how this requires an envisioned goal state. I refer to this assignment as a problem statement paper.

\section{A Problem is a Gap between a Current State and an Envisioned Goal State}

The paper must define a problem - which means making a case and supporting it. A persuasive problem definition makes clear the gap between current and desired conditions. The problem definition will be persuasive if the audience:

- Understands the current state.

- Understands the goal state.

- Believes the goal state is desirable (the leader may believe this, but the aim is to persuade others to believe it).

- Believes there is a gap between the current state and the goal state.

- Believes the goal state is possible to achieve.

- Believes the costs required to achieve the goal state are justified (i.e., worth the effort).

The problem statement must include a clear and specific problem sentence: what I call a "too little of" or "too much of" (TLO/TMO) claim. This is a sentence that states the core ("bottom line") problem. For instance, "there is too little learning-by-doing instruction in our science program," or "our school's drop-out rate is too high," or "enrollment in AP courses is too low." It is essential to write the core deficit precisely to express the problem and to counter the impulse to propose solutions before clarifying the problem; a clear and specific TLO/TMO statement also helps clarify the improvement goal. The writer must substantiate his/her argument with reasoning, literature, and evidence.

For instance, "there is too little learning-by-doing instruction in our science program" implies a gap: the desired state is "more learning-by-doing" and the current state is instructional practice 
lacking enough learning-by-doing. This claim, however, is not a problem definition. The writer must develop a vision of "learning-by-doing science instruction" to contrast with current instructional practice in the setting of concern to the problem definer. Making this vision persuasive requires not only knowledge of science instruction and learning; it also requires creating an attractive and motivating picture of what is possible - a vision of a better way.

A fully developed problem definition is challenging intellectual work. It requires reflecting on conditions in the organizational setting, examining local data, reviewing relevant literature, soliciting ideas and input from colleagues or peers, and strong communications skills - all of which are crucial to the exercise of vision in leadership.

Here is another example. A teacher-leader in an elementary school was concerned with weaknesses in assessment practices - the minimal use of "formative assessment." Her paper noted that all teachers routinely do "summative" assessment (e.g., exams or tests used to assign grades), but that sole reliance on summative assessments was deficient practice because without formative assessment teachers lack information for student-level progress monitoring and short term instructional planning. She wrote:

- Formative assessment monitors students' learning, identifies lagging students, and helps with the design of interventions (Goertz, Oláh, \& Riggan, 2009; Simpkins, Mastropieri, \& Scruggs, 2009). Research shows it boosts student achievement (Black, Harrison, Lee, Marshall, \& Wiliam 2003; Borich \& Tombari, 2004; McMillan, 2001).

Her paper described the difference between current practice and the envisioned goal state teaching and learning guided by formative assessment. Doing this meant she needed to know and describe what best practice looks like and why formative assessment helps raise achievement. She cited authoritative sources like those above as well as well known experts Black and Wiliam (1998).

Part of her paper depicts observed shortcomings of practice in her setting. She noted:

- We lack clear grade level learning objectives. Instruction is largely driven by text materials rather than by standards-based learning objectives. Recently, a districtsupported audit expressed concern the unclear grade level objectives hinders curriculum coordination between grades so students may have gaps in coverage as they move from one grade and subject to the next.

- Some formative assessments have been provided, but so far not used much. We have instructional kits with embedded assessments, but there use varies from teacher to teacher.

- Also, student self-assessment is not used much. Peer and student self-assessment are urged by leading experts, but have not been used consistently here.

Other portions of her paper provided examples of formative assessment and discussed data needed to design steps to implement change. 
In my course, the problem statement paper is the main assignment, but other related assignments can supplement the work. Students create presentations and other communications for designated stakeholder audiences. I develop supporting assignments requiring anecdotes and stories as persuasive tools (Boal \& Schultz, 2007; Danzig, 1997; Flemming, 2001; Guber, 2007), and also websites and graphics. Also, the paper can present inquiry plans to collect decision-oriented information.

\section{Concluding Comments}

Given the prominence of the concept of vision in leadership literature, I was surprised to discover almost no literature on the topic of teaching vision, despite extensive searching through a dozen journals related to leadership, management, and administration. Books and articles that address the topic of vision do so mainly by reviewing theoretical definitions, by advocating the practice of visionary leadership, by reporting research on this topic, and providing narrative accounts and anecdotes - stories about leaders with vision and how they made a difference. Certainly, readings like these are essential to develop learners' understanding of the concept of vision and its role in leadership. An additional instructional tool is the problem statement paper.

The problem statement paper is one way to help develop substantive knowledge and communications expertise to exercise vision. In a sense, the paper is like a simulation. The leader must convince others that current practices fall short of a goal state that is better and possible to achieve. Doing this requires substantive knowledge of the improvement advocated and proficiency with communications for multiple audiences and in multiple contexts. If the leader cannot do this, then change will be difficult. If the leader can do this, s/he is demonstrating the capacity to exercise vision.

\section{References}

Archbald, D. (2013). The GAPPSI method for problem-solving, planning, and communicating: Concepts and strategies for leaders in education. Ypsilanti, MI: National Council for Professors of Education Administration Press.

Archbald, D. (2008). Research versus problem solving for education leadership doctoral preparation: Implications for form and function. Educational Administration Quarterly, 44(5), 704-739.

Baker, E., \& Orton, S. (2010). Practicing management and leadership: Vision, strategy, operations, and tactics. Journal of Public Health Management and Practice, 16(5), 470472.

Barrett, J., Vessey, W., \& Mumford, M. (2011). Getting leaders to think: Effects of training, threat, and pressure on performance. The Leadership Quarterly, 22(4), 729-750.

Bennis, W. G. (1992). Managing the dream: leadership in the 21st century. Management Decision, 30(6), 166-168. 
Black, P., \& Wiliam, D. (1998). Inside the black box: Raising standards through classroom assessment. Phi Delta Kappan, 80(2) 139-147.

Black, P., Harrison, C., Lee, C., Marshall, B., \& Wiliam, D. (2003). Assessment for learning: Putting it into practice. New York: McGraw-Hill.

Boal, K., \& Schultz, P. (2007). Storytelling, time, and evolution: The role of strategic leadership in complex adaptive systems. The Leadership Quarterly 18, 411-428.

Boomer, L. G. (2012). Leadership, management and administration: What's the difference? Accounting Today, 26(9), 34-34.

Bollier, D. (1996). Aiming higher: 25 Stories of how companies prosper by combining sound management and social vision. AMACOM, Division of American Management Association, 1601 Broadway, New York, NY 10019.

Borich, G., \& Tombari, M. (2004). Educational assessment for the elementary and middle school classroom. Upper Saddle River, NJ: Prentice Hall.

Brenninkmeyer, L. D., \& Spillane, J. P. (2004, April). Instructional leadership: How expertise and subject matter influence problem solving strategy. Paper presented at the 2004 American Educational Research Association Annual Meeting, San Diego, CA.

Camburn, E., Spillane, J., \& Sebastian, J. (2010). Assessing the utility of a daily log for measuring principal leadership practice. Educational Administration Quarterly, 46(5), 707-737.

Conger, J. (1994). The dark side of leadership. In G. Hickman (Ed.), Leading organizations: Perspective for a new era, 250-260. Thousand Oaks, CA: Sage.

Conger, J. (1991). The language of leadership. Academy of Management Executive, 5(1), 31-46.

Copland, M. (2003a). Developing principals' problem-framing skills. Journal of School Leadership, 13, September, 539-548.

Copland, M. (2003b). Leadership of inquiry: Building and sustaining capacity for school improvement. Educational Evaluation and Policy Analysis, 25(4), 375-395.

Cuban, L. (2001). How can I fix it? Finding solutions and managing dilemmas. New York: Teachers College Press.

Danzig, A. (1997). Leadership stories: What novices learn by crafting the stories of experienced school administrators. Journal of Educational Administration, 35(2), 122-137. 
Dixon, D. L. (1999). Achieving results through transformational leadership. Journal of Nursing Administration, 29(12), 17.

Donaldson, G. A., Jr. (2007). What do teachers bring to leadership? Educational Leadership, $65(1), 26-29$.

Douglas, A., Burtis, J. O., \& Pond-Burtis, L. K. (2001). Myth and leadership vision: Rhetorical manifestations of cultural force. Journal of Leadership \& Organizational Studies, 7(4), 55-69.

Duch, B., Gron, S., \& Allen, D. (2001). The power of problem-based learning: A practical "how to" for teaching undergraduate courses in any discipline. Sterling, VA: Stylus Publishing, LLC.

Ekmecki, O. (2009). What would I do differently? Using first person voice to develop leadership identity for health care professionals. Journal of Leadership Education, 8(2), Fall, 41-49.

Fenwick, T. J. (2002). Problem-based learning, group process and the mid-career professional: Implications for graduate education. Higher Education Research \& Development, 21, May, 5-22.

Finnigan, K., \& Stewart, T. (2009). Leading change under pressure: An examination of principal leadership in low-performing schools. Journal of School Leadership, 19(5), September, 586-618.

Fleming, D. (2001). Narrative leadership: Using the power of stories, Strategy and Leadership, 29(4).

Frese, M., Beimel, S., \& Schoenborn, S. (2003). Action training for charismatic leadership: Two evaluations of studies of a commercial training module on inspirational communication of a vision. Personnel Psychology, 56(3), 671-698.

Goertz, M., Oláh, L., \& Riggan, M. (2009). Can interim assessments be used for instructional change? (CPRE Policy Briefs, RB-51). Graduate School of Education, University of Pennsylvania: Consortium for Policy Research in Education.

Gooch, S. (2012). A strong lead: Sally Gooch reveals the high cost of weak leadership and the need for swift and decisive action to banish poor care. Nursing Standard 26(43), 18-19.

Grogan, M., \& Andrews, R. (2002). Defining preparation and professional development for the future. Educational Administration Quarterly, 38(2), April, 233-256.

Guber, P. (2007). The four truths of the storyteller. Harvard Business Review, 85(12), 52-60. 
Handyside, E. (1997). Genba Kandri: The disciplines of real leadership in the workplace. Aldershot, Hampshire, England: Gower Publishing Limited.

Hackman, M., Kirlin, A., \& Tharp, J. (2004). Prescriptive leadership development: Developing tomorrow leaders today. The Journal of Leadership Education, 3(1), 1-9.

Horng, E., Klasik, D., \& Loeb, S. (2010). Principal's time use and school effectiveness. American Journal of Education, 116(4), 491-523.

Ibarra, H., \& Obodaru, O. (2009). Women and the vision thing. Harvard Business Review, January, 62-70.

Jean-Marie, G., \& Normore, A. (Eds.) (2010). Innovation and interdisciplinary approaches to the Ed.D. and graduate education. New York: Palgrave Macmillan.

Johnson, J. (2008). "Copers" and "transformers". Education Week, 27(45), August 13, pp. 26, 32.

Jonassen, D., \& Hung, W. (2008). All problems are not equal: Implications for problem-based learning. Interdisciplinary Journal of Problem-based Learning, 2(2), Fall, 6-28.

Koehn, N. F. (2002). Howard Schultz and Starbucks coffee company. Boston: Harvard Business School Publications.

Kotter, J. (1996). Leading change. Boston: Harvard Business School Press.

Kouzes, J. M., \& Posner, B. Z. (2009). To lead, create a shared vision. Harvard Business Review, $87(1), 22-21$.

Leithwood, K., \& Steinbach, R. (1995). Expert problem solving: Evidence form school and district leaders. Albany: State University of New York Press.

Leithwood, K., Louis, K., Anderson, S., \& Wahlstrom, K. (2004). How leadership influences student learning. Chicago: American Educational Research Association.

Leslie, J. (2009). What you need, and don't have, when it comes to leadership talent. Center for Creative Leadership. Greensboro, NC. [ww.ccl.org].

Manning, T. (2012). Managing change in hard times. Industrial and Commercial Training, 44(5), 259-267.

Marcy, R., \& Mumford, M. (2010). Leader cognition: Improving leader performance through causal analysis. The Leadership Quarterly, 21(1), February, 1-19. 
McGowan, P., \& Miller, J. (2001). Management vs. leadership. School Administrator, 58(10), 32-34.

McMillan, J. H. (2001). Secondary teachers' classroom assessment and grading practices. Educational Measurement, 20(1), Spring, 20-32.

Middleton, H. (2002). Complex problem solving in a workplace setting. International Journal of Educational Research, 3(1), 67-84.

Nanus, B. (1992). Visionary leadership: Creating a compelling sense of direction for your organization. San Francisco: Jossey-Bass.

O'Connell, D., Hickerson, K., \& Pillutla, A. (2011). Organizational visioning: an integrative review. Group \& Organization Management, 36(1) 103-125.

Owens, R. G. (2004). Organizational behavior in education: Adaptive leadership and school reform. Englewood Cliffs, NJ: Prentice Hall.

Pasi, R. (Ed.) (2003). Special issue: Visionary leadership. NASSP Bulletin, 87, December, 1-72.

Portin, B., Knapp, M., Daref, F., Feldman, S., Russell, F., Samuelson, C., \& Yeh, T. (2009).

Leadership for learning improvement in urban schools. Seattle, WA: Center for the Study of Teaching and Policy, University of Washington.

Savery, J. (2006). Overview of problem-based learning: Definitions and distinctions. Interdisciplinary Journal of Problem-based Learning, 1(1), Spring, 9-20.

Savin-Baden, M. (2000). Problem-based learning in higher education: Untold stories. Philadelphia: Society for Research into Higher Education \& Open University Press.

Schon, D. (1983). The reflective practitioner. New York: Basic Books.

Simon, H. (1973). The structure of ill-structured problems. Artificial Intelligence, 4(2), 181-201.

Simpkins, P., Mastropieri, M., \& Scruggs, T. (2009). Differentiated curriculum enhancements in inclusive fifth-grade science classes. Remedial and Special Education, 30(5), 300-8.

Slater, R. (1999). Jack Welch and The G. E. Way: Management insights and leadership secrets of the legendary CEO. New York: McGraw-Hill.

Snowden, D., \& Boone, M. (2007). Leader's framework for decision making. Harvard Business Review, 85(11) November, 69-76.

Strange, J. M., \& Mumford, M. D. (2005). The origins of vision: Effects of reflection, models, and analysis. The Leadership Quarterly, 16(1), 121-148. 
Taylor, V. (2007). Leadership for service improvement: Part 2, in the second of three articles, Vicki Taylor explains the importance of a "vision" of leadership. Nursing Management (Harrow), 13(10), March, 28-36.

Trice, H. M., \& Beyer, J. M. (1991). Cultural leadership in organizations. Organization Science, 2(2), 149-169.

Weiss, D. S., \& Molinaro, V. (2010). The leadership gap: Building leadership capacity for competitive advantage. Hoboken, NJ: Wiley.

Welch, J. (2013, June 21). Leadership quotation. Retrieved from http://www.brainyquote.com/quotes/quotes/j/jackwelch120692.html

Wilhelm, W. (1996). Learning from past leaders. In F. Hesselbein, M. Goldsmith, \& R. Beckhard, (Eds.), The leader of the future, 221-226. San Francisco: Jossey-Bass.

Yukl, G. (2001). Leadership in organizations. Englewood Cliffs, NJ: Prentice Hall.

Zaleznik, A. (1990). The leadership gap. The Executive, 4(1), 7-22.

\section{Author Biography}

Douglas Archbald is an Associate Professor Education Leadership and Policy in the College of Education and Human Development at the University of Delaware. His scholarly interests are in leadership development curriculum as well as in practitioners' use of data for purposes of school improvement. 